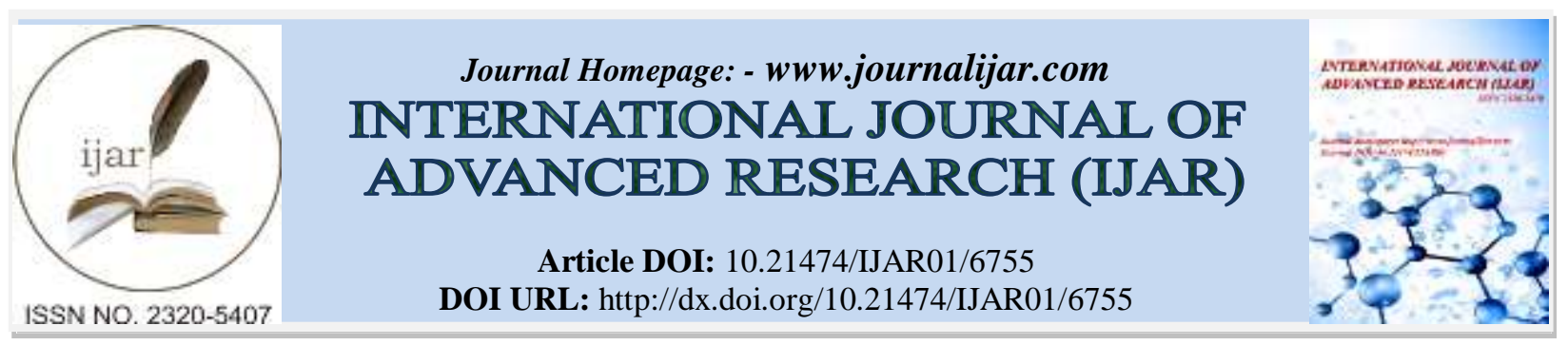

RESEARCH ARTICLE

\title{
EXAMINING THE LIVES OF TWO FEMALE SIDDHARTHAS.
}

Yoon Park and Lewis Seagull.

North london collegiate school jeju.

\section{Manuscript Info}

Manuscript History

Received: 15 January 2018

Final Accepted: 17 February 2018

Published: March 2018

Key words:-

Siddhartha, Tibet, nun, gender,

feminism.

\section{Abstract}

Two prominent 15 th century Tibetan nuns, Chokyi Dronma and Orgyan Chokyi, transcended the conventional gender stereotypes of their times to rise to spiritual prominence in Buddhism. Their rejection of the traditional limitations placed upon women resonates with the values of modern Western feminism and merits present-day examination. We will primarily focus on Chokyi Dronma, the pioneer, but will also examine the life of Orgyan Chokyi. The former was born to a royalty, and a life of comfort and wealth, while the latter was born in poverty. Both were forced to endure harsh treatment and abuse. The value to modern women is the notion that whether rich or poor, advantaged or disadvantaged, all women have to overcome obstacles inherent in societal norms. Each of these women achieved enlightenment by refusing to accept traditional female gender roles. Following her ordination, Dronma transformed a small Tibetan village into an economic stronghold, which required her to actively resist being treated as a dependent female. Her relentless efforts to obliterate negative gender stereotypes and sexist logic earned her the superlatives for which she is remembered. She transformed a community that was ill-prepared for an entirely new kind of exemplar of female leadership.

Copy Right, IJAR, 2018,. All rights reserved.

\section{Introduction:-}

Siddhartha is a compound word derived from the sanskrit meaning "he who has attained his goal." It is easy to see how this became an epithet for the Buddha. One should also immediately notice that the term is traditionally applied to a male priest. This paper will explore the lives of two women who lived centuries ago who, as Buddhist nuns, also achieved their spiritual goals and may rightfully lay claim to the name Siddhartha.

Chokyi Dronma, born to royalty in Fifteenth Century Tibet, and Orgyan Chokyi born in poverty two hundred years later, although women, both became spiritual icons in the male-dominated society of Tibet. In order to understand the story of these two women, it is necessary to understand Tibet, the expansive plateau region in today's Southwestern China. Modern Tibet shares borders with India, Nepal and Bhutan. For many Westerners, their exposure to Tibet is probably through the Hollywood film Seven Years in Tibet. Most people in the developed world 
have never set foot in Tibet, not to mention experienced life there firsthand. Even the few individuals who have been to Tibet have sometimes come back with a "quite distorted picture."

Because Tibet (... the "abode of snows") is situated virtually at the top of the world and is fortified on three sides by many of the highest mountains on earth, the country itself until very recently was framed for its very remoteness and inaccessibility. Those few travelers and explorers who managed to reach Lhasa, Tibet's capital city ...told of its magic and mysteries in grandiose and idealized fashion. Tibet was depicted as a type of "Shangri-la," as a country where the sheer vastness and stark beauty of nature itself caused heightened awareness; where peace reigned eternally, where the Buddhist religion permeated all facets of life at all times; where celibate monks and nuns were prized above all other citizens and where such clerics--by the thousands--chose to live a life apart in cloistered enclaves continually engaged in religious endeavors.

The rampant romanticization of Tibet can be problematic: "Such descriptions are a bit too idyllic and much too idealized. They present a static, capital-centered view of Tibetan life." In fact, the gamut of the workaday life in Tibet, from people's daily business to religious practices, is "much more dynamic, bustling, diverse, and fluid." 2 Especially, the existence of prominent female religious practitioners would add more diversity and amazement to the seemingly monotonous and monolithic landscape of Tibetan religious life.

As recently as 1959, a few years after the Chinese occupation of Tibet of 1950, there still lived many notable female Tibetan Buddhist practitioners of different kinds: they were spirit mediums, female religious bards, tantric adepts-meaning teachers--and Buddhist nuns. ${ }^{3}$ Still, female Tibetan Buddhist adepts were rare compared to their male counterparts. Even for the small number of women who represent the exceptions, few written records exist. ${ }^{4}$ Tibet was no exception to the low status of females in Buddhist religious life; they faced numerous barriers and were belittled by the religious establishment. Even so, the melodramatic, martyr-like charm they found in a spiritual life, "for some Tibetan wom[e]n...offered a viable, even attractive, means by which to practice their faith." ${ }^{\text {S }}$ Such stories of extraordinariness have remade their struggles into a tradition of their own.

This paper presents the lives of two prominent Tibetan nuns -- Chokyi Dronma and Orgyan Chokyi -- with an emphasis on the former, who defied their societal gender norms. Chokyi predated Orgyan by two hundred years, and was therefore the inspiration for the latter.

From a feminist perspective, the extent to which Chokyi Dronma strove for enlightenment by rejecting the female gender role merits attention even today. Her relentless efforts to obliterate negative stereotypes and sexist logic earned her the superlatives for which she is remembered. Following her ordination, she transformed a small Tibetan village into an economic stronghold. However, despite her prestigious personal background, Chokyi Dronma needed to demonstrate active resistance against feminization in order to effect a change in a community that was illprepared for an entirely new kind of exemplarity: Female leadership.

In contrast, Orgyan Chokyi's story unravels some thoroughgoing inequities of Tibetan society, its gender ideology, and the role of the Buddhist belief in the fifteenth and sixteenth centuries. Also, her story serves to contrast Dronma's narrative: While Dronma attained sainthood through her independent decisions, Orgyan did so by remaining steadfast to the recognized practices.

\section{Gender in Tibetan Buddhism:-}

Both Chokyi Dronma and Orgyan Chokyi in some ways defied traditional Tibetan Buddhism while in other ways each exemplified the traditions. In order to understand how this dichotomy existed, we must first understand Tibetan Buddhism. In Tibet, Buddhism has proved itself an excellent coping mechanism for the "impermanence of conditioned reality and the resulting inevitability of suffering and death" by providing an organic explanation for such inevitabilities in life: the karma doctrine. Both women whose lives we are examining experienced great

\footnotetext{
${ }^{1}$ Janice D. Willis, "Tibetan Ani-s: The Nun's Life in Tibet" The Tibet Journal, Volume 9, No. 4, A Special Issue (Winter 1984), p.16. www.jstor.org/stable/43302196

${ }^{2}$ Willis, "Tibetan Ani-s: The Nun's Life in Tibet," p.16.

${ }^{3}$ Willis, "Tibetan Ani-s: The Nun's Life in Tibet," p.15.

${ }^{4}$ Willis, "Tibetan Ani-s: The Nun's Life in Tibet," p.15.

${ }^{5}$ Willis, "Tibetan Ani-s: The Nun's Life in Tibet," p.19.
} 
suffering, as will be outlined in their biographies that follow. Both women were born to the traditions of Buddhism that spread to Tibet in the seventh century. Buddhism, especially its karma doctrine, has been central to Tibetan life: "Tibetans lean strongly on their Buddhist faith and believe in the doctrine of karma ... This is one of the reasons why Tibetans are very sympathetic, honest, cheerful, and satisfied with their lot. They are loyal, open, gentle, and kind."6

As with good works in Christian theology, in Tibet, opportunities were available to accumulate good karma, such as "donations to monks and religious institutions, offering of lamps and incense, recitation of scriptures, performance of prostrations and circumambulations, ransoming of animals from the butcher, and religiously valued actions of many other types."7 Furthermore, Buddhists seeking meritorious karma in Tibet were also encouraged to "turn from worldly activities to religious by taking refuge in the Three Precious Jewels: the Buddha, his teaching, and the religious community." In addition, the Buddhist establishment actively rewarded its lifelong devotees by providing them with rituals for the "passage of the dead," meant to guide the departed souls to auspicious rebirth. ${ }^{9}$

Both women faced the obstacle that the notion of femininity in Tibet was laden with negative associations, drastically limiting opportunities for success and self-development available to women: "to be a woman is to have bad karma, low status, and poor abilities." 10 Ani Dol-kar, a Tibetan Buddhist nun, herself claimed that "women can get spoiled more easily than men; so in a way the Buddha had predicted (correctly) that women wouldn't be able to practice all of his teachings." 11 In this respect, Tibetan women were not much better off than their counterparts in other East Asian societies, such as Korea, "where important ideological influence has been exerted both by Confucianism, in which the subordination of females to males is considered necessary, and by Mahayana Buddhism, in which female gender has been viewed as an impediment to salvation." 12

Dronma Chokyi was ahead of her time in understanding that gender was a social construct, a concept that gained credence in the twentieth century. Today, scholars agree that unlike sex, gender is socially constructed. Although one could be born a member of the female sex, this is not always true in a strict gender sense. The two concepts must be distinguished, scholars suggest, because gender is not inherently or innately embedded or endowed, but socially constructed. In The Second Sex, for instance, the feminist thinker Simone de Beauvoir drew a line between gender and sex: even a biological female is not a woman at the time of her birth; rather, she becomes one. In short, gender is artificially constructed through cultural and social conditioning. ${ }^{13}$

Thus, in the cultural milieu of Chokyi Dronma, in which several negative, pejorative notions were attached to the female gender, she was born into a highly privileged position. But her elevated social position did not create an exception to the rule that women aspiring to take unconventional roles had to transcend conventional gender ideology; she would live a life of continuous resistance against being gendered. She continued her efforts to free herself from the forces of social norms.

\section{Chokyi Dronma's Early Life in the Mundane World:-}

In order to understand how Chokyi Dronma defied the gender norms of her time, we should consider her biography. She was born in 1422 C.E. into a royal family in the kingdom of Gungthang. As a princess of the royal household, the young Dronma was adored by the members of her family, even though her mother had been expecting a son. Her first and major setback, which did play a greater part in her life decisions, arose when Dronma came of age. Around 1438 C.E., when she reached age sixteen, she was forced to marry Tsewang Tashi, the prince of Southern Lato. ${ }^{14}$

\footnotetext{
${ }^{6}$ Wangchuk Deden Shakabpa, Tibet, A Political History (New Haven: Yale University Press, 1967) p.18.

${ }^{7}$ Matthew Kapstein, The Tibetans (Malden, MA: Blackwell, 2006), p.216.

${ }^{8}$ Kapstein, Tibetans, p.216.

${ }^{9}$ Kapstein, Tibetans, p. 215.

${ }^{10}$ Ed. Janet Gyatso and Hanna Havnevik, Women in Tibet, New York: Columbia UP, 2005, p.9.

${ }^{11}$ Willis, "Tibetan Ani-s: The Nun's Life in Tibet," p.27.

${ }^{12}$ Clark W. Sorensen, "The Myth of Princess Pari and the Self Image of Korean Women,” Anthropos, Volume 83, Issue 4/6, (1988), p.403. www.jstor.org/stable/40463374

${ }^{13}$ Candace West and Don H. Zimmerman, “Doing Gender,” Gender and Society, Vol. 1, No. 2 (Jun, 1987), pp.125151. www.jstor.org/stable/189945

${ }^{14}$ Hildegard Diemberger, When a Woman becomes a Religious Dynasty: The Samdling Dorje Phagmo of Tibet

(New York: Columbia University Press, 1983), p.58.
} 
Although she had clearly expressed her desire to be married to the royal house of Guge, her father felt it necessary to pacify militant Southern Lato, which he saw as a potential threat to his kingdom of Gungthang. The Guge kingdom had maintained a close relationship with Gungthang and many of Gungthang heirs had been delivered by the daughters of the Guge royal family. ${ }^{15}$ Her father's decision was firm because he saw a political advantage to an alliance with Southern Lato, a potential threat to his kingdom; he judged that establishing a marital tie with its royal house was necessary to stave off that possibility. ${ }^{16}$

Because of the patriarchal attitudes of the society into which Dronma was born the birth of a male heir to one of her siblings all but dashed her political prospects in her native Gungthang. She was left with little choice: She was to marry Tashi.

On the day of her departure to Southern Lato, the world surrounding her mourned her departure; all of her people, including her mother, cried while showering her with precious gifts as they bade her farewell. Buddhist records hold that even all living creatures, flora and fauna, had joined the human population in mourning over her departure, saluting the woman of an extraordinary and superhuman nature: "All the living beings of Ngari (Gungthang) felt as if they had lost their protector. It was as if the whole essence of the earth had been taken away and the earth had turned bleak." 17

As if her marriage against her will had been an ill omen, her married life was full of conflicts with her husband and her in-laws, especially with her mother-in-law. These run-ins were not petty domestic quarrels; they reflected the patriarchal nature of the socio-religious situation in Tibet at the time. Her new husband, Tashi, and his family were not Buddhists, like Dronma was. Tashi and his family belonged to an indigenous religion called the "Bonpo," or the "Bon," which was different from Buddhism, although the two shared many commonalities. ${ }^{18}$

It was not unusual for a prominent family like Tashi's not to be Buddhists. Today we may think of Buddhism as the popular religion of Tibet, but in the time of Dronma it was viewed by most Tibetans as an alien belief. Buddhism was not the first religion of Tibet. For a long time, both Buddhism and the Bonpo enjoyed equal popularity. Since it reached Tibet via Nepal in the seventh century, Buddhism spread at a snail's pace, taking another whole century to spread all across the mountainous region. Although the exact cause for its slow propagation is currently unknown, Tibet eventually became a stronghold of Buddhism. ${ }^{19}$

Based on her actions alone, it would appear as though Chokyi Dronma, who made little effort to hide her unease about her in-laws' Bonpo worship, was never able to wholeheartedly accept her husband's belief. When a Bonpo priest was invited to perform a series of rituals on the day of her wedding at her would-be husband's royal palace in Southern Lato, Dronma had clearly articulated: "I am a Buddhist; I am not a worshipper of the Bonpo. Please respect my beliefs!" 20 She had repeatedly made the request that her religion, Tibetan Buddhism, be respected.

Her husband remained unswayed. The two frequently clashed over issues of worship. Tashi would insist on his prerogatives as a husband, to which Dronma would object ardently. After he again brought a Bon priest over to bless their daughter, who soon died, she excoriated him, ascribing her daughter's untimely death to Tashi's irreverence toward Buddhism. ${ }^{21}$ Her disapproval of the Bon may strike one as somewhat intolerant or narrow-minded; however, such judgment must take her predicament into account: she did so to protest her in-laws' hostility toward her religion, having been driven into a corner by those who were downright dismissive of her beliefs.

Their mutual intolerance of each other's beliefs paved the way for possibly the most climactic moment in Dronma's married life. When Dronma declared to her husband's family that she would leave their household to become a Buddhist nun, the flash point of the conflict shifted to what others construed as an act of desertion.

\footnotetext{
15 Diemberger, When a Woman becomes a Religious Dynasty, p.55.

${ }^{16}$ Diemberger, When a Woman becomes a Religious Dynasty, p.55.

${ }^{17}$ Diemberger, When a Woman becomes a Religious Dynasty, p.56.

${ }^{18}$ Kapstein, Tibetans,. p.45-50.

${ }^{19}$ Shakabpa, Tibet, A Political History, pp.17-8.

${ }^{20}$ Diemberger, When a Woman becomes a Religious Dynasty, p.159.

${ }^{21}$ Diemberger, When a Woman becomes a Religious Dynasty, p.166.
} 
Dismayed by her idea of abandoning her family, her mother-in-law doggedly discouraged her. Dronma remained adamant. The young Buddhist aspirant's action reached a point of absurdity in her last-ditch effort to assert her will: She chopped off almost all her hair with a knife! She did so in so such a vehement and hasty manner that she wounded herself by the knife blade and blood started to trickle down her face: "The lady's shaved head was an awful sight, wet like a skin container for churning butter full of buttermilk.",22

Her mother-in-law, in tears, entreated Dronma, contending that her departure would cause her husband, who had already developed a manic depression and begun showing erratic behavior, to die: "If this is how you are going to behave, Tshewang Tashi has no other option but to die, and I would rather die first!" ${ }^{23}$ Dronma, however, had no regrets, for she had planned it beforehand: "Now, by carrying out the gentle action [of shaving her head], nothing meaningful has been achieved. I have to do something unheard of." 24

Dronma's action, if drastic and grotesque, lends important insight into her psyche. Amid the domestic turmoi in the Dronma household, her recourse to extreme action might have been inevitable, given the stubbornness of her inlaws. But more importantly, she probably wanted to fully vindicate her sincerity and prepare for an honorable exit by proving herself incapable of meeting their expectations. By shaving her head, she was making a definitive statement that she was unable to be the woman they expected her to be. Her long hair, a symbol of womanhood, was replaced with an androgynous, almost genderless, look.

Ironically, her shaved head demonstrated to her in-laws' the fruitlessness of their efforts. In fact, Dronma's motherin-law, Lady Tsencham Gyalmo, had just hinted at her wish for a grandson. After she glanced at her newborn granddaughter, she expressed her wish for a male heir in two pithy sentences: "There is no difference between boy and girl. Later you will give birth to one child after the other."25 Gyalmo's desire for a grandson could be read between the lines; her latter sentence elucidating the innuendo the former unsuccessfully disguises.

Gyalmo insisted that Dronma be dedicated to her womanly duties. When Chokyi Dronma declared that she would no longer be able to look after her daughter, Gyalmo immediately expressed her disheartenment: "She hasn't been seeing her child! Even wolves or hawks take care of their offspring." 26 In short, it is plain that, on one hand, Chokyi Dronma was expected to perform all the duties expected of a woman in marriage pursuant to the dictates of her society's gender ideology, and on the other, her struggle was to demonstrate how wrongheaded her in-laws were to demand her to conform unconditionally. Had it not been for Chokyi Dronma's decisive gesture, Gyalmo might have never permitted her daughter-in-law, who occupied an instrumental role in the family, to take her leave.

The demands of the family into which she had married were a spur to action, but Chokyi Dronma's resistance was ultimately an attempt to define herself. She was not abused or harassed, nor had she been mistreated; she was not reacting against her present misery. Rather, she was troubled by her own circumstance as a married woman, left to choose between her present life and one as a great nun.

Lacking any other excuse, she realized that she simply had to insist on the authenticity of her decision, or, failing that, act on her will through earnest endeavor. Abandoning her family without permission was out of the question, for such an act of irresponsibility would imply her inability to persuade. At least, running away in such a lowly manner would have diminished the loftiness of her purpose. In a decisive stunt, she demonstrated her wish to leave her worldly life behind and embark on her path of enlightenment.

\section{The Role of Pain: the Sufferings of Chokyi Dronma and Orgyan Chokyi}

Like her idol, Chokyi Dronma, Orgyan Chokyi experienced conflicts with the people around her. The causes for their conflicts were very different, but there is little doubt that these conflicts strengthened their shared desire to lead a religious life. As shall be seen in the next part of this essay, a complex psychology of pain seems to have been at work in the two women's lives. Clearly, the ways in which they reacted to pain were influenced by their closely-held

${ }^{22}$ Diemberger, When a Woman becomes a Religious Dynasty, p.171.

${ }^{23}$ Diemberger, When a Woman becomes a Religious Dynasty, p.171.

${ }^{24}$ Diemberger, When a Woman becomes a Religious Dynasty, p.171.

${ }^{25}$ Diemberger, When a Woman becomes a Religious Dynasty, p.163.

${ }^{26}$ Diemberger, When a Woman becomes a Religious Dynasty, p.165. 
beliefs about the logic of karma. This doctrine of causality, led the figures to sublimate their trauma into love instead of retribution.

From the beginning of her life, Orgyan Chokyi was involved in a struggle with her family over her role. This struggle directly related to her decision to seek a life of seclusion. Unlike Chokyi Dronma, who was born into a royal family two centuries earlier, Orgyan Chokyi was born into a family of low social standing and modest means. Her family life in the mountainous area of the Himalayas, was markedly different from that of Chokyi Dronma: aside from her poor family background, her mother had no auspicious conception dream and Chokyi possessed no prodigious talent.

Even so, these facts hardly begin to describe the misfortunes she would undergo. Her father, who suffered from leprosy, constantly blamed his daughter for his prolonged ailment. Her mother also demonstrated little affection for her own daughter, overtly expressing her resentment toward her. Chokyi herself described her unfortunate childhood: "As I remembered now, from five to ten years of age there was suffering, yelling, unnecessary beating, and the food was not good."27 Both of her parents physically abused Orgyan Chokyi, believing that she was the root cause for all their hardships. Once, when Chokyi's grandmother had her cow and its calf stolen by an unknown thief, it was Orgyan Chokyi who took all the blame. ${ }^{28}$ Crying sorrowfully, she ran to her father, who, instead of comforting her, brutally assaulted her: "[I] went to father, and got hit. Dirt got into my mouth and my hair, and then a rock went down my mouth."29 Her mother treated Chokyi as a jinx: “"Girl, you tell awful stories!"”30

These unfortunate experiences underlie Orgyan Chokyi's determination to seek a religious life. In Tibet, monastic life promised many women a viable alternative to their less-than-ideal circumstances. Going further, one can even argue that misfortune could also mean an opportunity for cultivating compassion, a crucial ingredient for Buddhist enlightenment. As a matter of fact, most of the women who chose to withdraw from the mundane world to devote themselves to religious practice in retreat were not as fortunate as the princess, Chokyi Dronma. The majority of female adepts [teachers] had often been subject to intolerable hardships before coming to monasteries or nunneries. For instance, Ani Dol-kar, a twentieth-century nun, explained that she had chosen to become a nun due to the loss of her children, which had brought her insurmountable sadness and trauma:

I gave birth to four children: two sons and two daughters.

My first child, a son, was born when I was eighteen years old.

He did not survive. I later had three other children--four altogether

--but none of them lived ... Then I prayed ....and asked many

lamas about my fate; and I was told that 'religion is very deep. ${ }^{31}$

It becomes obvious in the quotes from the lamas' advice that Organyi's personal traumatic experiences would help her devote herself to religious pursuits: "You think hard before becoming a nun. It is not an easy life. Think about whether you really want to do it. You have had no peace as a householder. You have suffered much. So, if you think you can really do it, becoming a nun is very good."32

In Orgyan Chokyi's case, her traumatic experiences first sowed the seeds of her internal anguish. However, when she later became an ordained nun, she not only overcame her trauma but also extended her compassion to her parents by singing a song in their memory, filled with words of sympathy and compassion for their ignorance and impermanence. Thus, her anguish contributed to her later mindfulness toward all finite living beings. In Buddhism, followers of the Buddha's teachings are all expected to cultivate compassion for all sentient creatures as one of the ways to gain merit or good karma, which is believed to promise a rebirth into favorable conditions. ${ }^{33}$ To interpret

\footnotetext{
${ }^{27}$ Kurtis R. Schaeffer, Himalayan Hermitess: The Life of a Tibetan Buddhist Nun (New York: Oxford University Press, 2004), p.134.

${ }^{28}$ Schaeffer, Himalayan Hermitess, p.134.

${ }^{29}$ Schaeffer, Himalayan Hermitess, p.134.

${ }^{30}$ Kurtis R. Schaeffer, "The Autobiography of a Medieval Hermitess: Orgyan Chokyi (1675-1729)" in Ed. Janet Gyatso and Hanna Havnevik, Women in Tibet, New York: Columbia University Press, 2005, p.89.

${ }^{31}$ Willis, "Tibetan Ani-s: The Nun's Life in Tibet," p.25.

${ }^{32}$ Willis, "Tibetan Ani-s: The Nun's Life in Tibet," p.25.

${ }^{33}$ Matthew T. Kapstein, The Tibetans,. pp.216-7.
} 
Organyi's career as a nun in terms of this Buddhist ideology, her channeling of pain into love should be understood as an eminent success.

Still, transcendence first required enduring unimaginable pain. A closer inspection of Orgyan Chokyi's adolescence reveals a child whose memories of repeated violence came back to haunt her, putting her in a constant state of agony. Adding to her physical pain was the emotional affliction that attended that violence. Her father cursed her as he beat her like a disease-bearing animal. ${ }^{34}$ Later, when her mother started to teach her domestic work, she verbally abused her, throwing hurtful words at her: "If a low-born girl does not know how to work with wool, from where will happiness come to you?" 35 Before Organyi could react, her mother proceeded to throw a spindle and a weaving shuttle at her's head. ${ }^{36}$

Once such violence became a recurrence in her life, Orgyan Chokyi reiterated the expression, "Untold mental anguish came to me" whenever she was abused by her parents. ${ }^{37}$ After she was abused by her father, upset about his lost cattle, and her mother, she visited the temple of Shapku, where she met the monk Kunga Pendar and Ani Paldzom to heed their counsel. ${ }^{38}$ They consoled her with sweet words of solace. As a mere female child who was suffering deeply, this first pleasant encounter with these two helpful Buddhists taught her, for the first time, to find solace in spirituality: "She [Ani Paldzom] brought solace to my mind. I was feeling both joy and sorrow, and I wept a great deal. ${ }^{\prime 39}$

As for Chokyi Dronma, the principal cause of her pain was her own aspirations. While Orgyan Chokyi took no assertive action in front of her parents who had inflicted on her unbearable pain, Dronma took the matter into her own hands. As Dronma became anxious that she might lose the opportunity to achieve her ordination altogether, she could no longer tolerate her in-laws, who were obstructing her path. Chokyi Dronma's choice to aggressively shave off most of her hair was an effort to free her of that painful state. However, paradoxically, this also brought her unforeseen pain - humiliation and a physical injury. In fact, if her in-laws had given her the permission to leave the family, she might not have felt compelled to demonstrate her wish with such intensity. Nevertheless, since her inlaws incessantly prevented her from pursuing a religious life, she was virtually forced to injure herself to get her way.

Both Orgyan Chokyi and Chokyi Dronma experienced physical pain related to their embarkation on a religious life. On a basic level, the causes for their physical pain seem to be very different, largely unrelated to each other. However, they share a commonality in a sense that pain served as a major stimulus and turning point. The continued physical afflictions engendered mental anguish inside of Orgyan Chokyi, led to her search for solace in religious life. Chokyi Dronma's suffering was first brought on by her persistence with her wish, then again by her putting that wish into action. Her physical injury became a symbol of severance from the ordinary world. Her blood indicated her rebirth as a woman of devotion. Last but not least, their experiences, especially Dronma's, indicate, in a uniquely ironical manner, that no matter how hard one struggles to free oneself from suffering, it will simply lead to more. Therefore, because of the ubiquitous presence of pain in our lives, to free oneself from it, one must embrace its place in life, elevating it for noble purposes.

\section{The Role of Retreat:-}

Both Chokyi Dronma and Orgyan Chokyi chose to temporarily isolate themselves from the rest of the world. They would leave their families behind in the mundane world and move into a reclusive area, where they could completely dedicate themselves to religious practices. Since life is suffering, according to Buddhism, there is no way to avoid or escape whatever pain one is born into. The only solution would be achieving the so-called "nirvana, the enlightenment of a Buddha. ${ }^{" 40}$ However, it is a truism that only a handful, if any, of Buddhist practitioners could reach such an advanced level while alive; it is arguable that it was but a dream to accomplish nirvana, the consummate stage of enlightenment.

${ }^{34}$ Schaeffer, "The Autobiography of a Medieval Hermitess: Orgyan Chokyi (1675-1729),” p.89.

${ }^{35}$ Schaeffer, Himalayan Hermitess, p.135.

${ }^{36}$ Schaeffer, Himalayan Hermitess, p.135.

${ }^{37}$ Schaeffer, Himalayan Hermitess, p.134-5.

${ }^{38}$ Schaeffer, Himalayan Hermitess, p.134.

${ }^{39}$ Schaeffer, Himalayan Hermitess, p.134.

${ }^{40}$ Kapstein, Tibetans, p. 215 . 
Eventually, most Buddhist followers resort to more realistic methods to alleviate suffering in their lives to come: accumulation of merit through donation; cultivation of compassion for all creatures, and self-isolation from the human world in order to completely dedicate themselves to the teachings of Buddha while in retreat. Then, it seems very probable that female Buddhists equally desire to gain meritorious karma as much as their male counterparts by following more or less the same paths of entering retreat.

For women, however, the bar was set much higher than for men. Women could be respected as adepts [teachers] and acknowledged for their accomplishments only if they had demonstrated exceptional performance, overcoming the difficulty of proceeding to advanced religious practices far beyond prayer. Generally, it appeared that ordinary nuns were not able to benefit much, if at all, from monastic life; they often suffered abjectly from deplorable living conditions and were put to continuous hard labor, as well as facing disapproval and resistance in advancing to higher-level practices.

In fact, female practitioners were generally expected to be satisfied with their daily prayers as nuns, instead of striving to go beyond such limits on religious practice. However, even if this could have precluded most of the women practitioners from progressing beyond the status of ordinary nuns, there were indeed, though few, exceptional women who had overcome even such restrictions. The barrier-breaking accomplishments by those nuns who have been honored and recognized for their exceptional performance in areas such as spiritual integrity and wisdom, were a handful of exceptions to the rule: Machik Lapdrön in the twelfth century, Yeshé Tsogyel the eighth century, Mingyur Peldrön the seventeenth century, and Shuksep Jetsünma in the nineteenth and twentieth centuries, are some of such rare examples. ${ }^{41}$

These female adepts had proven themselves to excel and even outdo others by a tremendous margin, but not by following same prescribed paths. These outstanding female practitioners shared certain features, though: they belonged to Tibetan Buddhist orders and lineages that prioritized the handling of liturgical matters over abstract learning conducted in a scholarly style, which remained a bastion of male privilege. Primarily, these matters encompassed a wide range of preparations necessary for the proper implementation of rituals and meditation. Another commonality found among female adepts is that most female adepts came from above-average families. One such example would be Mingyur Peldrön (1699-1769), the daughter of the Nyö family who became the heir due to the untimely death of her male siblings after a raid by Zunghar Mongols in 1717, who played a major role in restoring her deteriorating monastery. The main figure of this essay, Chokyi Dronma, too, fits this description. However, we shall see that it was not her extraordinary background alone that enabled her to become a stellar woman practitioner and later leader of a religious community consisting of her followers, nor did her expertise in abstract learning alone earn her such status. Instead, she had acquired relevant skills required for running a community of her own, such as building the infrastructure for agriculture and making profits for the benefit of her community, utilizing her exceptional leadership and acumen.

Thus, retreat was not mere reclusion or withdrawal from society. Especially, considering the fact that most female practitioners, forced to juggle between religious pursuit and duties as housewives at home, were not able to solely devote themselves to solitary religious practice during their retreat, these two women were fortunate enough to fully concentrate on religious practice.

And yet, as the two women devoted themselves to their practice, they did not just merely take in the teachings, but also learned to develop their own perspectives or ways of thinking and genuine competence. These foundations were instrumental for their later contributions upon their return to society. In the case of Chokyi Dronma, it is evident that retreat was her practice of choice. Not only was she born into a royal family and married another imperial household in a nearby kingdom, but she also was gifted with extraordinary talents. ${ }^{42}$ Thus, it is safe to conclude that she was already a prominent member of the mainstream society. It might have rather been difficult for an ordinary person to pursue religious life in a remote area, leaving all the benefits of society behind. For Dronma, the departure from the material world rang true with her desire for a life cleansed of materiality and, more importantly, worldly conventions. To get closer to her goal, these elements must be replaced with prolonged acts of prayers and

\footnotetext{
${ }^{41}$ Kapstein, The Tibetans, p.200.

${ }^{42}$ Diemberger, When a Woman becomes a Religious Dynasty, pp.152-9.
} 
meditation. In truth, her search for solitude was not really geared at attaining personal peace. She saw it as a challenge that demanded overcoming. Consequently, she needed this crucial experience in order to reach her goal.

Since she was a prodigy already by the time of her birth, Chokyi Dronma mastered the teachings of Tibetan Buddhism very quickly as if she had learned or heard about them before. ${ }^{43}$ However, the most important lesson that she had garnered while in retreat was the significance of transcending who she was. Her noble and wealthy birth was at times as much an impediment as it was an enabler. While her prominent status allowed her a higher degree of freedom than other women, for instance Orgyan Chokyi, it also made it unlikely for her to get in touch with meaner, baser elements and experiences which nonetheless could be conducive to spiritual growth, according to Buddhist teachings. It is likely that Chokyi Dronma was aware of her limitations, so her willingness to dedicate herself to alms-begging seems to be a reflection of her active effort to overcome it: she had wholeheartedly devoted herself to the duties of alms-begging, claiming on the eve of the embarkation of her mission, "Alms begging is the essence of monastic life taught by the Buddha." and later once again, "This is just an ordained person's duty." 44 Her almsbegging journey provided her with ample opportunities not only to reach out to lay people, but also to observe and witness how the world she lived in worked.

Of course, the local population would not hide their astonishment when seeing a princess collecting alms just like any other conventional nun. ${ }^{45}$ Dronma had already known that she must bear compassion for all living beings, from an old woman without any accumulated merits to even lice swarming over human bodies. ${ }^{46}$ Her sympathy for people grew more intense following her ordination. In one account, Dronma was visiting her mother when she became deeply affected by the sight of an old woman who had badly wounded herself after falling off a high bridge. When Dronma learned about the woman by chance she immediately expressed the desire to help her: "If this old woman has not died yet, please send someone to bring her to me. If she has died, please send someone to take proper care of her body." 47 Devastatingly, nobody else was willing to take care of the old abandoned woman; even Dronma's own mother, who suspected that the woman might have been infected with a contagious disease, tried to discourage her daughter from helping the unfortunate soul. However, Dronma, in keeping with her religious teachings, insisted on carrying out what she had learned: "We used to pray to the bodhisattvas and promise that we would help all livings beings. How can we not feel sorry for someone when we face a real situation, but only talk about it? Therefore I'll go to see her on my own." 48 Although she was in the middle of retreat, during which one must renounce one's interest in other matters than meditation and prayer, she refused to ignore the sufferings of people outside of her religious community. Here, her strong feelings for the laity indicates that Chokyi Dronma remained loyal to the humanly world. It is an early instance that foreshadows her later acts of similar compassion, in which she assumed an active role in her order as a leader who worked to promote people's well-being.

During her retreat, Orgyan Chokyi chafed under the rampant hostilities in her new environment. Orgyan Chokyi's religious career was first characterized by a continuation of menial labor she probably had enough of already. Her male Buddhist master would neither allow her to go into retreat nor let her write an autobiography of hers. ${ }^{49}$ Her experience is in line with the discriminatory treatment commonly meted out to women; too often, they were left to to cope with it as part of their manifest destiny. ${ }^{50}$ Especially, when women came to monasteries seeking higher religious education, rarely open to women, they were instead made to spend most of their time doing dull chores.

Orgyan Chokyi became frustrated by the incessant kitchen work required of her: "in the kitchen of mistaken conventional reality, with no leisure day or night, I was saddled with the work of food and drink." 51 Her purpose for retreat was to find solitude necessary for prayer and meditation. However, her daily chores in the kitchen continually distracted her from concentrating on her Buddhist practices. Her master did not respond in kind when she complained about her trouble and asked for relief: reprimanding her, he claimed "You are wrong to be unhappy at

${ }^{43}$ Diemberger, When a Woman becomes a Religious Dynasty, p. 153.

${ }^{44}$ Diemberger, When a Woman becomes a Religious Dynasty, pp.177-9.

45 Diemberger, When a Woman becomes a Religious Dynasty, p.61, 178-9.

${ }^{46}$ Diemberger, When a Woman becomes a Religious Dynasty, p.153.

${ }^{47}$ Diemberger, When a Woman becomes a Religious Dynasty, p.205.

${ }^{48}$ Diemberger, When a Woman becomes a Religious Dynasty, p.205.

${ }^{49}$ Ed. Gyatso and Havnevik, Women in Tibet, p.10.

${ }^{50}$ Ed. Gyatso and Havnevik, Women in Tibet, pp.9-10.

${ }^{51}$ Schaeffer, Himalayan Hermitess, p.157. 
the kitchen. Men are just right for the field, women are just right for the kitchen." ${ }^{52}$ However, her determination was left unscathed by her master's sexist, chauvinistic logic; she continued to appeal to him to be released from her kitchen duties. When her repeated pleas were met with refusal, she felt burned by the false promise that she would gain enough solitude upon entering the monastery: "Now I am an elder. Let me not be around too many people. Let me not work in the kitchen. Let the little ones engage in the bustle. The work at the monastery is no different from mundane work. ${ }^{, 53}$ She felt that the chores in the kitchen consumed her gradually; they hobbled her devotion to religious pursuit. Although she risked others' disapproval by breaking away from the traditional female gender role, she realized that such departure was inevitable for her unimpeded growth.

In Buddhism, the preoccupation with earthly thoughts and relationships was thought to have deleterious effects on one's spiritual training, which demanded its practitioner's undivided attention. The continuous bombardment of worldly notions, logics, fixed ideas, stigmas, biases, prejudices could all detract from achieving disinterestedness and an absolute purity of mind, the goal of Buddhist meditation. In the same vein, the chief purpose of monastic life was to help practitioners carve out a completely new mindset. Isolated from the conventional world, disciples learned to think in a radically de-centered manner. Meditations and spiritual dialogues were meant to shake up the earthly logics and notions that they had depended on for so long; they must surmount the challenge of transcending their conventional mentality. From early on, Chokyi Dronma made this effort more forcefully than Orgyan Chokyi. She had acted in accordance with the Buddhist credo of rising above the conventional paradigm. She rejected deepseated intolerance and biases favored not only by the mundane world, but also by the male-dominated, homosocial Buddhist establishment. These included the negative, unfavorable, and some downright absurd notions ascribed to the female gender. One by one, Dronma proved them wrong with her outstanding achievements. Orgyan Chokyi, though resistant to such unfair treatment, did not demonstrate her desire to reject misogyny as intensely. Instead, she often showed signs of submission or acquiescence: "This female body is itself samsara [endless cycle of rebirth] the round of existence. May I attain a male body, and keep the vows, May I never again be born in the body of a woman!" ${ }^{54}$ Hence, physical isolation figured more importantly in her development. Only through retreat could she attain a state which was normally beyond the reach of a woman. This quasi-disembodied state, in which she was free from the confines of gender stereotypes, allowed her to cultivate the transparent mind of the bodhisattva, the enlightened one.

Though monasteries were blighted by their share of entrenched prejudices and discriminatory practices, it is probable that these extraordinary and excellent female visionaries could not have achieved so much if they had not immersed themselves in monastic life. The term "retreat" encompasses a variety of meanings; on the whole, it covers all efforts to forget or "tune out" the mundane world as practitioners focused their energies on religious practices and mastering the rituals and teachings of the Buddha. It usually implies, but not limited to, a thorough isolation from the outer world. After all, many monasteries had developed and maintained tight connections with their neighboring communities; "monks and layfolk lived in such close association, joining in so many activities together..." ${ }^{55}$ Above all, the lives of female practitioners continued to be intertwined with those prior to their dedication to religious practices from house chores to various family issues as we will see below in the case of Tibetan nun Ani Dol-kar. She in fact received a stern warning by her teacher not to practice retreat to the point where she abandoned her family in exchange for her devotion to Buddhism.

He told me not to enter the nunnery (there) since I had to take care of the children [i.e. her siblings, her father and mother having died since her marriage and she being the eldest of their six children]; but to go into retreat from time to time whenever I could. So I did whatever he advised me to do; no derivation from that!"56

As demonstrated in this representative case, female practitioners were expected to continue carrying out their roles as housewives and daughters while remaining committed to their monasteries or nunneries. They performed all household duties while straining to achieve mastery of Buddhist practices, teachings, and rituals. ${ }^{57}$ Ani Dol-kar, too, had diligently fulfilled her expected duties for her family while pursuing her devotion. As she eloquently confessed:

\footnotetext{
${ }^{52}$ Schaeffer, Himalayan Hermitess, p. 160.

${ }^{53}$ Schaeffer, Himalayan Hermitess, p.161.

${ }^{54}$ Schaeffer, Himalayan Hermitess, p.100.

55 David Snellgrove and Hugh Richardson, A Cultural History of Tibet (Bangkok: Orchid Press, 2003) pp.247-8.

${ }^{56}$ Willis, "Tibetan Ani-s: The Nun's Life in Tibet," p.26.

${ }^{57}$ Kapstein, The Tibetans, p.219.
} 
"in Tibet, I would finish one ...retreat, then return home to check on the family. Then another ...retreat, then return home to check on the family. Then another ...retreat, and then home again." 58 Female practitioners often had to juggle all their roles - domestic chores and retreat - at the expense of free time and other conditions they so needed for concentrating on their religious development.

Although nunneries to which religious women were assigned rarely had as much resources as all-male monasteries, they could provide practitioners with relevant lessons through other means. Non-religious activities, including but not limited to administrative and economic ones, not to mention chances for vicarious learning by observing others carry out their jobs, seemed to have played a similar role as the more scholastic aspects of their training. ${ }^{59}$ Trying to fathom their precise contributions can be a complicated undertaking, however. To simply assume that such outside chores built patience and strength for later success is to run the risk of reading too much into their realities using modern standards. At the end of the day, as we have seen in our two figures' cases, each individual responded differently to these requirements. I suspect Chokyi Dronma could have benefitted in the same manner as Orgyan Chokyi did had she complied more with the instructions handed down from her elders.

As the "institutional heart of Tibetan Buddhism," monasteries occupied a central position in Tibet, taking on various functions from education to the cultivation of the arts, making monastic life attractive for those yearning to make far-reaching impacts on their society, both culturally and politically. ${ }^{60}$ Especially becoming a member of a monastery, mainly as monks, was considered extremely prestigious and meritorious not only for themselves and their families but also for the society as a whole. In other words, the more the monks, the more meritorious the karma created and shared for their communities. As a result, because becoming a monk was believed as a way to gain both fame and merit, many families had donated their sons to monasteries. ${ }^{61}$ Of course, no one could deny that

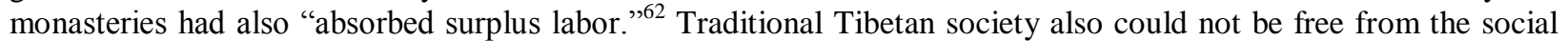
problem of unemployment and monasteries played a role alleviating the situation by providing jobs; becoming a monk was virtually meant being hired at monasteries. Therefore, monastic education came to address the spiritual, political, material, and cultural needs of Tibetan society as a whole.

For nuns, religious practice was often sidelined by such petty house chores as cooking and doing laundry. Here, we can see how the pejorative notions about women went hand in hand with the expected roles imposed on religious females at nunneries. Even if the actual cause for religious women's poor performance was their lack of opportunity to fully dedicate themselves to the Buddhist learning and training, the predominance of negativity made it look as if women would still fail even if they were guaranteed equal opportunities their male counterparts enjoyed. Given the circumstances, it is understandably ironic that the unfavorable circumstances were in fact crucial for achieving extraordinariness. Achievement must be viewed as a reaction to their present oppression.

In conclusion, our women visionaries made diametrically opposed decisions in response to the challenges that lurked in monastic life. The key determinant was found in their particular circumstances. There are certain similarities and differences between the stories of the two women: Orgyan Chokyi, who encountered the same domestic toil, attempted to break free from conventionalities. By doing so, she could balance her development by obtaining a chance to focus on abstract learning. Chokyi Dronma, by contrast, wholeheartedly embraced the practical over the abstract. Her bold deviation from her status allowed her to absorb many hands-on lessons that could otherwise be difficult to learn. In sum, the key to spiritual growth was to be found in appropriately reacting to one's own conditions, not in uncritically following conventions. This conclusion is also supported by the accounts of other visionaries, might not have gained their status had they not made similarly heterodox decisions, as noted before in my paper. At any rate, independent decisions were inevitable because set procedures were almost nonexistent. Paradoxically, their later creativity and rugged individualism proved vital in demonstrating their excellence and gaining official recognition. We might consider their mindful reaction to their setbacks to be quintessentially Buddhist in nature.

\section{Chokyi Dronma's Return to Society as Leader:-}

${ }^{58}$ Willis, "Tibetan Ani-s: The Nun's Life in Tibet," pp.26-7.

${ }^{59}$ Kapstein, The Tibetans, p.219.

${ }^{60}$ Kapstein, The Tibetans, p.219.

${ }^{61}$ Kapstein, The Tibetans, p.219.

${ }^{62}$ Kapstein, The Tibetans, p. 219. 
Notwithstanding the fact that these women had not completely excluded themselves from society even during their retreat, upon the attainment of ordination they undertook great efforts to promote the welfare of their communities. There are considerable differences between the two in relation to their contributions: Chokyi Dronma played a proactive role as a leader of her community, whereas Orgyan Chokyi practiced very moderate, sometimes passive, roles - mainly praying for people - and remained reclusive until the end of her life.

Their lives in the mundane world must not exert much impact on their religious life in retreat, for they were strongly encouraged to sever their ties with the world outside of their monastic communities completely. In addition to the physical isolation, they must learn to "think out of the box," thoroughly transcending the prevalent notions, logics, and their personal experiences in the mundane world. They must also think up fresh ideas and master a wide variety of skills required for leading people and for later running a community of their followers. In short, they were left to grind on their own to become somebody they had never been before. Thus, in the biographies of Chokyi Dronma and Orgyan Chokyi, they describe how gravely they had taken their mission of self-transformation after the completion of their training for ordination.

The retreat completely changed Chokyi Dronma into a spirited religious leader who was well-versed with various capabilities. Alms-begging was just the beginning of her break with her former selfhood as a princess; she acquired new abilities during her retreat that enabled her to transcend her innate weaknesses which might have obstructed her later accomplishments. Chokyi Dronma played several important roles for her new community. Chokyi Dronma, now unlike a princess, demonstrated her adeptness in commercial activities necessary for a secure economic base for her community. She exquisitely managed economic activities to reap financial benefits, which was eventually channeled back to her community. Of course, as a princess she already inherited tremendous wealth from her mother: "a good land tenure where the master and his disciples used to reside. [...] a good storeroom for barley (nas khang) built in Kuthang [in Nubri] [...] presents and instructions to her retinue." ${ }^{63}$ In addition, numerous visitors, including her parents and followers, offered substantial amounts of alms and donations. Thus, Chokyi Dronma already had an enormous leg up in primary capital, enough perhaps for her monastic community to count on. However, Dronma had a broader vision toward the future, seeking more sustained and extensive ways of providing benefits to the members of her monastic community in Palmo Choding, where it was based. Her apostles learned by her example, ensuring a secure future for the community after her passing.

Her first order of business was to establish an irrigation channel for her people, though in the end her endeavor never materialized. The result alone should not blind us from seeing other aspects of her ambitious construction project. Before she arrived in Palmo Choding, she had been wandering from place to place in her own region, Gungthang (also called Ngari). Though her motivation and purpose for coming to this new region is not clearly established, it is obvious that her transformation of the area resulted in a productive and sustainable outcome. But she was firm with her condition that she would stay only if she had been allowed to construct water channels. It is more than probable that she saw unexploited opportunities lay in the barren region and that she was highly aware of the significance of water channels for building a community. She later reiterated this point:

The construction of the channels in the area of the Palkhu Lake (a lake in Palmo Choding) will benefit as area measuring one thousand khal. Everybody will benefit as long as no one raises a claim for a larger share. ... Also, the ... surrounding fields would produce large amounts of rice, and numerous learned monks from many places would gather here to study and practice his collected works, spreading the doctrine of the Buddha." ${ }^{\circ 4}$

As she announced her desire, she added that these water channels should draw water into the fields, also to be dug up along with the irrigation channels, and that they should support the community intended as a future central location for Buddhist teaching and learning.

Chokyi Dronma did not just stop at enunciating her desire and reasons for constructing water channels; she herself participated in the actual construction process, giving directions and guidelines. ${ }^{65}$ She accomplished this both by her leadership and by the sweat of her brow. Perhaps her wandering should be understood as part of her training in leadership: in fact, on her way to Palmo Choding, she dropped by Ganden, where she first supervised the

${ }^{63}$ Diemberger, When a Woman becomes a Religious Dynasty, p. 210.

${ }^{64}$ Diemberger, When a Woman becomes a Religious Dynasty, p. 212.

${ }^{65}$ Diemberger, When a Woman becomes a Religious Dynasty, pp.211-2. 
construction of water channels. Thanks to her great teacher, Omniscient Great Lord Chogle Namgyal. she had already come away with first-hand knowledge of building water channels by the time she reached Palmo Choding. Now was the time for her to demonstrate her knowledge by teaching the workers of Ganden the steps for making water channels. Having vigorously imparted her knowledge to others, she had proven her capacity beyond the realm of Buddhist practices, both mastering and spreading practical knowledge and expertise. As a Buddhist practitioner, mastering the doctrines and rituals could be enough to receive recognition. However, Dronma's notable step forward involved much more than the purely religious. In order to qualify for a leading position on real-world terms, knowing how to promote and sustain the welfare of people was equally crucial. Above all, although she was tolerant and compassionate for all living beings, she had no interest in refraining from setting high standards, as can be seen in her conversation with the people of Palmo Choding:

She gave lengthy instructions on how to build channels and everybody said, "We're sure that our channels will be excellent!" She said, "It's difficult for you to carry out the work to my satisfaction, but making channels is important to benefit the doctrine and living beings.",66

Her tone was strict and charismatic yet remarkably persuasive. Hence, she fulfilled another major requirement for becoming a Buddhist leader: cultivating and practicing ingenuity following the renunciation of worldly precepts that clouded the mind. It is believed that the extent to which one acquired new abilities reflected the degree of success with purification.

Aside from her august accomplishment in the realm of spirituality, Dronma truly knew how to do business: she would make every effort to maintain friendly relationships with other merchants as a way of generating long-term profits. Her excellence in conducting transactions did not come from selfish motives: "The next day she paid all the workers. She also sold some items to them according to their request and for a price that was one fourth of the real price that would have been asked by good traders. In this way she kept all the workers happy." ${ }^{\text {"67 }}$ Dronma prized sustainable partnerships with her business relations. As a leader, promoting the welfare of other people had a direct impact on her ability to attract and retain her followers, who in turn would contribute to her monastic community. Her plan to construct an irrigation channel was also a reflection of her prudence; not only was there no guarantee for a continuous flow of donations and alms, but she was also eager to pass on the benefits to outside people - traders who conducted business with her - who were not an integral part of her community.

After all, Chokyi Dronma's expressions of tolerance, respect, and compassion for people in relatively lower social strata were reflections of her dedication to Buddhism. The fact that one practices Buddhism mattered much more than the person's official social status. After she married into her husband's family living in Shekar, Southern Lato, one day Drungchen Kyabma, an official from Northern Lato, paid her in-laws a visit. Dronma showed no interest in employing any honorific languages or gestures; "she received him simply, without using any honorific language and proper protocol."68 Her mother-in-law was incensed by this behavior. Conversely, later when she encountered an ordinary monk carrying water from the Shekar monastery, she wasted no time in offering him a seat; he was looking for a place to sit with a heavy water pot, but could not find one easily because he was only allowed a certain seat for a person of his rank. Dronma immediately accommodated his need: "Using her hand, she showed him a place and with great respect requested him to be seated there." ${ }^{69}$ Such stark contrast in her actions between the two occasions left her husband bewildered. Once again, this future Buddhist leader would not refrain from articulating the relevance of her action: "Even though the water carrier has very low rank," she proudly said, he is a monk. My ancestors who were bodhisattvas [...] behaved with great kindness toward all living beings and showed great respect to those who were wearing the monastic robes. ... The water carrier is a son of the Buddha and he should be respected. $^{70}$

Her compassionate and thoughtful treatment of the low monk shows that she had exercised the same respect for all people, but when it came to Buddhist practitioners, she could not help being even more respectful.

\footnotetext{
${ }^{66}$ Diemberger, When a Woman becomes a Religious Dynasty, p.211.

${ }^{67}$ Diemberger, When a Woman becomes a Religious Dynasty, p.202.

${ }^{68}$ Diemberger, When a Woman becomes a Religious Dynasty, p.160.

${ }^{69}$ Diemberger, When a Woman becomes a Religious Dynasty, p.161.

${ }^{70}$ Diemberger, When a Woman becomes a Religious Dynasty, p.161.
} 
What should be noted here is that Buddhism had always been the utmost priority for her. Nothing came close to it. She willingly sacrificed other things for her religion. Take, for example, alms begging. Since alms begging was part of Buddhist practice, she had shown no reluctance at all for carrying it out. However, when she first announced her plan to do so to the people around her, they tried to dissuade her, stressing that alms begging was irrelevant to a woman from a royal family. ${ }^{71}$ In reaction, Dronma insisted that alms begging was so essential a Buddhist practice that anyone aspiring to become fully ordained could never be exempt, in any event, from such a grave, transformative requirement. ${ }^{72}$ Her conviction left others embarrassed of what they had said previously. It is only obvious that she was so strongly devoted to Buddhism that she was willing to take on whatever hampered her from fulfilling all the mandates.

Conclusion

From the beginning, Chokyi Dronma and Orgyan Chokyi were indeed two completely different women. Chokyi Dronma was born with more than everything a person could manage to have in their lifetime. She was born into a royal family, where she was surrounded by people who adored her. Growing up, she showed superior talents only few others possessed. On the other hand, Orgyan Chokyi was one among many ordinary girls in a poor rural area of the Himalayas. She was not fortunate enough to be born into either a royal family or wealth. To make matters worse, her birth was not a welcomed or blessed one. Her upbringing was marred by incessant suffering - the ruthless verbal and physical abuses of her parents. Nevertheless, the fact that the two vastly different figures both achieved ordination demands some explanation.

It is told that in the world of Buddhism, the path to ordination is completely distinct from the logics, institutions, and elements of the mundane world. For this reason, all of those who pursue a religious life for ordination in retreat become totally equal in a sense that they are all placed on the same starting point. Eventually, the steps that they take could lead to an astonishing parallel. One of the striking similarities is physical pain, found most commonly in the stories of female visionaries in Tibet. Another renowned Tibetan nun, Yeshe Tsogyal, also suffered several cases of abuse, in which her body had been severely wounded. Prior to her ordination, she was courted by two men, who coerced her into marrying them without success. As Yeshe Tsogyal tried to escape, she was captured by one of them. However, in this process, she was terribly injured and her body became soaked with the blood she shed. This injury does not have any direct connection to her ordination, but it fortified her enormously: Later, she would remain calm and steadfast in the face of physical threat. After her ordination, she was brutally raped by a gang of thieves. Despite her physical pain, she, in a gesture of transcendence, gave the thugs a blessing. These scattered accounts portray physical pain as a recurrent theme in the lives of female visionaries; even though their physical pain is primarily related to their physical weakness, it ironically serves to change their lives in a dramatic way.

Corporeal pain is also central to our examples. In the case of Chokyi Dronma, her self-injury was required for convincing her in-laws of her sincere intent. As for Orgyan Chokyi, a series of verbal abuses and assaults by her parents subjected her to a deep mental anguish. However, this did not simply remain as agony; instead, her unfortunate childhood experiences encouraged her to spontaneously seek refuge in religious devotion in a place far removed from the mundane world. Therefore, physical pain could be found at the juncture between their life in the mundane world and their religious practice in retreat.

The time in retreat allowed both Dronma and Chokyi to cultivate the singleness of heart by leading them through diversified experiences that they needed. Becoming a religious leader did not simply mean being more knowledgeable in academic religion; it meant embodying the values for which ordinary people admired them. Dronma wandered around Tibet begging for alms precisely because she lacked the experience of the ordinary practitioner. Chokyi, on the other hand, used her time in solitude to cultivate boundless, unconditional compassion for all living beings, including her parents, who abused her. Through these quite different experiences, they learned what it meant to lead a Buddhist life - to live in complete devotion to its core values.

Upon her achievement of ordination in retreat, Chokyi Dronma demonstrated a series of extraordinary skills even in purely worldly issues such as trading goods, hiring various workers, and planning the construction of the irrigation channel to water the fields, which in turn sustained the entire community she led. Of course, one may wonder what, if Chokyi Dronma never completely severed her ties with the mundane world, it was that made her accomplishments

${ }_{72}^{71}$ Diemberger, When a Woman becomes a Religious Dynasty, pp.177-8.

${ }^{72}$ Diemberger, When a Woman becomes a Religious Dynasty, p.178. 
particular remarkable with respect to the Buddhist teachings. Interestingly, it is this particular elusiveness that makes Buddhism so distinctive and dynamic. While it would appear that there exist clear provisions for the fulfillment of ordination, there may be no such thing, in fact. The precise stages one must go through vary from one individual to another, as is patently true of our two figures. Chokyi Dronma's active involvement in the plebian society brought her strong suit to the fore: Leadership. For Orgyan Chokyi, an adequate distance from the mundane world, which had wounded her, was crucial for her to remake her torment into a positive force. Even her parents, with their history of brutality and cold-bloodedness, later received Chokyi's blessings.

Chokyi Dronma's extraordinariness is notable in that it resonates even with the values pertaining to modern Western feminism. Her refusal to accept the dominant gender ideology of her culture bears a striking resemblance to the activism of prominent feminist figures in the West: from Mary Wollstonecraft to Simone de Beauvoir to Marlene Dietrich to Betty Friedan, great feminist leaders have fought not only for equal rights, but also for the equal expression of gender. In The Feminine Mystique, Betty Friedan famously denounces the destructive effects of modern American femininity on women, arguing that we can "no longer ignore that voice within women that says: 'I want something more than my husband and my children and my home.",73

The last and perhaps most important reason Dronma's story is so exceptional is that its moral straddles both the spiritual world of Tibetan Buddhism and modern Western liberal individualism. It is as though the paradigmatic Buddhist enlightenment parable is recast for the average modern audience. It traverses all the stages of pain, cleansing, and spiritual rebirth, only to return to worldly illustriousness. Even so, it is still quintessentially Buddhist, as it does not fail to speak to the Buddhist ideal of advancing the well-being of others. In short, her growth and recognition reveals what centrally constitutes a genuine -male or female - leader: Catholicity.

\section{Bibliography}

Diemberger, Hildegard. When a Woman becomes a Religious Dynasty: The Samdling Dorje Phagmo of Tibet. New York: Columbia University Press, 1983.

Friedan, Betty. The Feminine Mystique. New York: W. W. Norton, 1963.

Gyatso, Janet and Hanna Havnevik, eds. Women in Tibet. New York: Columbia UP, 2005.

Clark W. Sorensen, "The Myth of Princess Pari and the Self Image of Korean Women," Anthropos, Volume 83, Issue 4/6, (1988). www.jstor.org/stable/40463374

Kapstein, Matthew. The Tibetans. Malden, MA: Blackwell, 2006.

Schaeffer, Kurtis R. Himalayan Hermitess: The Life of a Tibetan Buddhist Nun. New York: Oxford University Press, 2004.

Kurtis R. Schaeffer, "The Autobiography of a Medieval Hermitess: Orgyan Chokyi (1675-1729)" in Ed. Janet Gyatso and Hanna Havnevik, Women in Tibet. New York: Columbia University Press, 2005.

Shakabpa, Wangchuk Deden. Tibet, A Political History. New Haven: Yale University Press, 1967.

Snellgrove, David and Hugh Richardson. A Cultural History of Tibet. Bangkok: Orchid Press, 2003.

West, Candace and Don H. Zimmerman, "Doing Gender," Gender and Society, Vol. 1, No. 2 (Jun, 1987), pp.125151. www.jstor.org/stable/189945

Willis, Janice D. "Tibetan Ani-s: The Nun's Life in Tibet" The Tibet Journal, Volume 9, No. 4, A Special Issue (Winter 1984). www.jstor.org/stable/43302196

\footnotetext{
${ }^{73}$ Betty Friedan, The Feminine Mystique (New York: W. W. Norton, 1963), 32.
} 
